\title{
ESTIMATION OF SORGHUM SUPPLY ELASTICITY IN SOUTH AFRICA
}

\author{
Motsipiri Calvin Mojapelo $^{1 \bowtie}$, Johannes Jan Hlongwane $^{1}$, Abenet Belete ${ }^{\mathrm{l}}$ \\ ${ }^{1}$ University of Limpopo, South Africa
}

\begin{abstract}
This study aims to estimate sorghum supply elasticity in South Africa. The study used time series data spanning from 1998 to 2016, obtained from the abstracts of agricultural statistics. The Variance Error Correction Model was employed; the study used two dependent variables, these being area and yield response functions. The results have shown that the area response function was found to be a robust model as most of the variables were significant, responsive and elastic. Maize price, as a competing crop for sorghum, negatively influenced the area allocation; however, the remaining variables had a positive impact on area allocation in the long-run. The yield response function was found not to be robust and hence not adopted. It was therefore concluded that the area response function is more robust than the yield response function, hence sorghum production has shown more response to area allocation than yield. The findings further indicated that the error correction term for area and for the yield response function was -1.55 and -1.30 , respectively. This indicated that the two models were able to revert to equilibrium. Based on the findings, the study recommends that amongst other methods to enhance sorghum output, producers could use improved varieties or hybrids, as this action would result in allocation of more land to sorghum production, following price change.
\end{abstract}

Keywords: sorghum, supply, elasticity, error correction model, South Africa

\section{INTRODUCTION}

Sorghum is a tropical cereal crop that has been cultivated in Southern Africa for over 3,000 years. Globally, the production is approximately 70 million tons of grain from about 50 million hectares of land. It is the dietary staple of more than 500 million people in more than 30 countries (National Agricultural Marketing Council, 2007). Sorghum is still largely a subsistence food crop, but is increasingly becoming the foundation for successful food and beverage industries. Sorghum is the $5^{\text {th }}$ most important crop after wheat, maize, rice and barley in South Africa (DAFF, 2010). The sorghum farming community in South Africa can conveniently be divided into the smallholder and commercial farmers owing to the differences in farm sizes and in production and marketing methods.

According to DAFF (2015), major production areas of sorghum in South Africa are: the Free State province which is the largest sorghum producing area and delivers on average $54 \%$ of the total domestic sorghum crop. Mpumalanga is the second largest sorghum producing province $(28 \%)$, followed by Limpopo (7\%), North West province (5.8\%) and Gauteng (5\%). The following are part of sorghum producing areas: Eastern Cape, KwaZulu-Natal, Northern Cape and Western Cape provinces. In South Africa, the total quantity of sorghum produced annually fluctuated between 450,000 and 150,000 tons, depending on the total area planted to sorghum and the yields obtained (Sihlobo and Kabuya, 2015). Therefore, this study attempted to consider the response of sorghum production to changes in price and non-price factors.

According to Belete et al. (1995), the estimation of supply function can be explained using two different

\footnotetext{
${ }$ Motsipiri Calvin Mojapelo, Msc, Agricultural Economics Programme, University of Limpopo, Polokwane, 0727, South Africa, e-mail: mamohlake@gmail.com, https://orcid.org/0000-0003-2962-1081
} 
dependent variables, which is quantity supplied and crop land. Additionally, the study backed-up their arguments by mentioning that the reason why acreage is used as a dependent variable is that farmers can have control over the kinds and quantities of inputs (seeds, fertilizer, labor, land etc.) they employ in production but not over output. This concept was supported by Munyati et al. (2013) who stated that area cultivated is mostly used as a proxy variable for actual output in the supply model. However, actual output is the most preferable. Area was chosen because it reflects the decisions of farmers to plant more of the crop, as farmers decide how many hectares to plant sorghum. Alhaji et al. (2014) postulated that cultivated area has been favored over production since farm production is similarly influenced by weather conditions which are beyond the farmers' control. The idea of yield response to price is further supported by earlier discussion in the literature that the area function might underestimate the actual level of supply response. Taking account of the various arguments and justifications above, this study used both acreage and output as dependent variables and eventually considered one of them based on the significance of coefficients of the two models.

\section{MATERIALS AND METHODS}

\section{Sources of data}

Time series data of a 19-year period spanning from 1998 to 2016 was employed. Variables included in this study were: rainfall $(\mathrm{mm})$, technology advancement (trend), sorghum area planted (ha), sorghum total output (ton), sorghum price (ZAR) and maize price (ZAR). Data on sorghum, rainfall and maize was obtained from $\mathrm{Ag}$ ricultural Statistics published by DAFF. The data was verified by South African Grain Information Service (SAGIS). Data on sorghum was collected in the nine provinces as the crop is produced throughout the country. Maize was incorporated in the study as a substitute product for sorghum. Average annualized data on rainfall; maize producer price; sorghum hectares; sorghum output and sorghum producer price were employed. Nominal producer prices for both sorghum and maize were deflated by the producer price index to remove the effects of inflation.

\section{Modeling sorghum supply elasticity}

The Error Correction Model (ECM) was used to analyze short-run and long-run dynamics in the model. It has two distinct characteristics: first, an ECM is dynamic in the sense that it involves lags of the dependent and explanatory variables; it thus captures short-run adjustments to changes of particular adjustments into past disequilibria and contemporaneous changes in the explanatory variables. Second, the ECM is transparent in displaying the cointegrating relationship between or among the variables (Paltasingh and Goyari, 2013). This model was used to estimate the agricultural supply response by a number of researchers, including Mutua (2015), McKay et al. (1998), Mose et al. (2017), Anwarul Huq and Arshad (2010).

The Error Correction Model is expressed as follows:

$$
\Delta Y t=\alpha \Delta X t-(Y t-1-\beta X t-1)+v t
$$

where:

$v$ - is a disturbance with zero mean, constant variance, and zero covariance

$\alpha$ - measures the short-run effect on $y$ of changes in $x$

$\beta$ - measures the long-run equilibrium relationship between $y$ and $x$.

$$
Y t=\beta X t+U t
$$

$Y t-1-\beta X t-1$ measures the "errors", i.e. divergences from the long-run equilibrium, and corresponds to the residuals of a lagged version of (1). $X$ measures the extent of correction of such "errors" by adjustments in $y$ (Hallam and Zanoli, 1993).

\section{Justification of the choice of research method}

The Nerlovian methodology seems unable to give an adequate clear-cut distinction between short-run and longrun elasticity, while the use of Ordinary Least Squares (OLS) may produce spurious results (Nerlove, 1958). The linear programming model was not used as it handles complex multi-relationships at farm level, which exposes it to a lot of econometric errors (Nmadu, 2010). Furthermore, the Autoregressive Distributed Lag approach (ARDL model) was not employed either because it does not distinguish between stationary and nonstationary variables. Another difficulty involved in the ARDL approach is the decision regarding the number of endogenous and exogenous variables to be included in the supply model, as well as the time lags applicable to each variable. In this context, it became clear that the Error Correction Model is suitable for this study as it measures the divergence of 'errors' from the long-run equilibrium, corresponds to the residuals of a lagged 
Table 1. Description and measurement of variables

\begin{tabular}{|c|c|c|}
\hline Variables & Description & Measurement unit \\
\hline \multicolumn{3}{|l|}{ Dependent variable } \\
\hline $\begin{array}{l}\text { Sorghum supply } \\
\text { elasticity }\end{array}$ & $\begin{array}{l}\text { The response of total output to price and non-price factors. This study has two } \\
\text { dependent variables, namely: area response function and yield response func- } \\
\text { tion. (Shoko, 2014; Belete, 1995; Nmadu, 2010) etc. }\end{array}$ & $\begin{array}{l}\text { Area (acreage), } \\
\text { equivalent to } 100 \text { ares } \\
\left(10,000 \mathrm{~m}^{2}\right) \\
\text { Yield (ton/ha) }\end{array}$ \\
\hline \multicolumn{3}{|l|}{ Independent variables } \\
\hline Sorghum price & Actual producer price of sorghum per ton. & ZAR/ton \\
\hline Sorghum area planted & Represents the area of sorghum planted annually. & Hectare \\
\hline Sorghum output (yield) & Refers to the actual total output/yield of sorghum produced annually. & Tons \\
\hline Rainfall & Average amount of rainfall received annually. & Millimeters (mm) \\
\hline Maize price & Producer price of maize per ton (as a substitute product). & ZAR/ton \\
\hline $\begin{array}{l}\text { Technology advance- } \\
\text { ment (time trend as } \\
\text { proxy) }\end{array}$ & $\begin{array}{l}\text { Improvement in the knowledge of sorghum farmers; seed varieties; GMO; } \\
\text { extension services and mechanization. }\end{array}$ & Trend \\
\hline
\end{tabular}

Source: own elaboration.

version and provides a clear cut between the short-run and long-run elasticity (Paltasingh and Goyari, 2013).

\section{RESULTS AND DISCUSSION}

This section presents the results from the diagnostic tests and the two models, these being the area and yield response functions used in this study. Diagnostic tests must be applied to ensure that the study does not produce spurious regression results.

Table 2. Summary of diagnostic tests applied

\begin{tabular}{ll}
\hline \multicolumn{1}{c}{ Test } & \multicolumn{1}{c}{ Method } \\
Unit root test & Augmented Dickey Fuller (ADF) test \\
Serial correlation & Breusch-Godfrey LM test \\
Cointegration & Johansen cointegration test \\
Stability test & Ramsey RESET test \\
\hline
\end{tabular}

Source: own elaboration.

\section{Augmented Dickey Fuller (ADF) test}

The ADF test states that the null hypothesis $\left(\mathrm{H}_{0}\right)$ should be rejected if the absolute value of the test statistics is greater than the critical values at $1 \%, 5 \%$ and $10 \%$ significance levels. Area of sorghum (sorghumha) and sorghum output (sorghumton) were stationary at $10 \%$ critical value, while technological change (tech) and average annual rainfall (rainfall) were stationary at $1 \%$ critical value. However, two variables, namely: real producer price of sorghum (realsorprice) and real producer price of maize (realmaizeprice), were not stationary. The series was stationary at first difference I(1). Indeed, the null hypothesis that the series is not stationary was rejected, and the series was concluded to have a unit root.

\section{Serial correlation test}

The null hypothesis $\left(\mathrm{H}_{0}\right)$ that the data is serially correlated was rejected, meaning that there is no serial correlation among variables (Gujarati and Porter, 2009). If the $p$-value for any of the lag levels is less than 0.1 , then $\mathrm{H}_{0}$ is rejected at the respective significance level, and the conclusion is that the disturbance terms are uncorrelated (StataCorp, 2011). 
Table 3. Unit root test using the ADF test

\begin{tabular}{lccccc}
\hline \multicolumn{1}{c}{ Variables } & ADF test statistics & $10 \%$ critical value & Lag length & $p$-value & Decision \\
\hline LnSorghumha & 2.700 & 2.630 & 0 & 0.0740 & Stationary \\
LnSorghumton & 2.914 & 2.630 & 0 & 0.0437 & Stationary \\
LnTech & 27.798 & 2.630 & 0 & 0.0000 & Stationary \\
LnRealsorprice & 2.412 & 2.630 & 0 & 0.1384 & Non-stationary \\
LnRealmaizeprice & 1.714 & 2.630 & 0 & 0.4240 & Non-stationary \\
LnRainfall & 4.287 & 2.630 & 0 & 0.0005 & Stationary \\
Results of unit root test at first difference & & & & \\
LnRealsorprice & 4.246 & 2.630 & 1 & 0.0006 & Stationary \\
LnRealmaizeprice & 2.978 & 2.630 & 1 & 0.0370 & Stationary \\
\hline
\end{tabular}

The critical values were $3.750,3.000$ and 2.630 at significance levels of $1 \%, 5 \%$ and $10 \%$ respectively. Source: own elaboration.

Table 4. Lagrange multiplier (LM) test for autocorrelation

\begin{tabular}{cccc}
\hline Lag & $\mathrm{Chi}^{2}$ & df & Prob $>$ chi $^{2}$ \\
\hline 1 & 2.4770 & 4 & 0.64876 \\
2 & 5.4470 & 4 & 0.24443 \\
\hline
\end{tabular}

$\mathrm{H}_{0}$ : no autocorrelation at lag order

Source: own elaboration.

\section{Cointegration}

The Johansen co-integration test is based on the maximum likelihood (ML) estimation and two statistics: trace statistics and maximum eigenvalues. If the rank of the matrix is zero, cointegration does not exist. However, if it is greater than zero, there are a number of cointegrating relationships equal to the maximum rank (Johansen, 1988). At a maximum rank of zero $(r=0)$, the trace statistics (29.8343) is greater than the critical value (20.04), thus the null hypothesis on the absence of cointegrating equations was rejected. However, when $r=1$, the trace statistics (4.1410) is lower than the critical value (6.65). Hence, the null hypothesis that there is at least one cointegrating equation could not be rejected. In conclusion, there is at least one cointegrating equation among the series. Therefore, the ECM was specified with the inclusion of one cointegrating equation (Hallam and Zanoli, 1993; Nerlove, 1958 and Alemu, et al., 2003).
Table 5. Johansen cointegration test

\begin{tabular}{cccc}
\hline $\begin{array}{c}\text { Maximum } \\
\text { rank }\end{array}$ & Eigenvalue & $\begin{array}{c}\text { Trace } \\
\text { statistics }\end{array}$ & $\begin{array}{c}1 \% \text { critical } \\
\text { value }\end{array}$ \\
\hline 0 & - & 29.8343 & 20.04 \\
1 & 0.77939 & $4.1410^{*}$ & 6.65 \\
2 & 0.21619 & - & - \\
\hline
\end{tabular}

The asterisk $(*)$ indicates the point at which the null hypothesis will be rejected (where the critical value exceeds trace statistics). Source: own elaboration.

\section{Stability condition of VECM estimates}

The null hypothesis $\left(\mathrm{H}_{0}\right)$ that the model has omitted variables was rejected; the alternative hypothesis $\left(\mathrm{H}_{\mathrm{a}}\right)$

Table 6. Eigenvalue stability condition

\begin{tabular}{ccc}
\hline Eigenvalue & Modulus & \\
\hline 0.3592958 & $+1.037711 \mathrm{i}$ & 1.09815 \\
0.3592958 & $-1.037711 \mathrm{i}$ & 1.09815 \\
1 & 1 & \\
-0.0253561 & 0.025356 & \\
\hline
\end{tabular}

The VECM specification imposes a (1) unit modulus. Source: own elaboration. 
that there are no omitted variables was thus accepted (Mutua, 2015). It was deduced that the stability condition was met and the specified VECM imposes one unit modulus on the companion matrix. This implies that the respective ECM terms are able to bring back the system to equilibrium after a shock (Johansen, 1988 and StataCorp, 2011).

\section{Area and yield response models}

\section{Model one: area response function}

LnRealsorprice, the short-run single-lagged real price of sorghum, influenced the area allocation at a $10 \%$ significance level. Hence, the coefficient of 0.99 meant that a one-rand (ZAR 1.00) increase in the price of sorghum will result in an increase in the area under sorghum production by 0.99 hectares. This was inelastic and implied that when own price increases, the planned hectares of sorghum are likely to increase in the subsequent period. However, the increase in acreage is relatively smaller than the change in prices. The long-run own price was statistically significant at $1 \%$ with a coefficient (1.74)

Table 7. Model 1, VECM results: area/acreage response function

\begin{tabular}{lcccc}
\hline \multicolumn{1}{c}{ Variables } & $\begin{array}{c}\text { Short-run } \\
\text { elasticities }\end{array}$ & $\begin{array}{c}\text { Test } \\
\text { sta- } \\
\text { tistics } \\
(z)\end{array}$ & $\begin{array}{c}\text { Long-run } \\
\text { elasticities }\end{array}$ & $\begin{array}{c}\text { Test } \\
\text { sta- } \\
\text { tistics } \\
(z)\end{array}$ \\
\hline LnSorghumha $_{\mathrm{t}-1}$ & -0.17 & -0.27 & 1 & - \\
LnSorghumton $_{\mathrm{t}-1}$ & $0.77 * * *$ & 1.60 & $0.85^{*}$ & -15.55 \\
LnTech $_{\mathrm{t}-1}$ & $8.4 * * *$ & 1.76 & $3.78^{*}$ & 2.11 \\
LnRealsorprice $_{\mathrm{t}-1}$ & $0.99 * * *$ & 1.62 & $1.74^{*}$ & 8.76 \\
LnRealmaizeprice $_{\mathrm{t}-1}$ & $-0.49 * * *$ & -1.84 & $-1.15^{*}$ & 1.81 \\
LnRainfall $_{\mathrm{t}-1}$ & $0.89 * * *$ & -1.72 & $1.69^{*}$ & -5.90 \\
Constant & 13.15 & 0.39 & -161.85 & - \\
Error correction term & $-1.55^{* * *}$ & 1.78 & $-1.55^{* * *}$ & 1.78 \\
Adj. ${ }^{2}(0.76)$ & & & & \\
Log likelihood $(0.97)$ & & & & \\
$P>$ chi $^{2}(0.0005)$ & & & & \\
\hline
\end{tabular}

*** Significant at 10\%.** Significant at 5\%. Significant at $1 \%$ Source: own elaboration. greater than unity. This implies that area allocation is more responsive to the price of sorghum in the long than in the short-run. Similar results were found by the following authors: Mutua (2015); Townsend and Thirtle (1997) and Shoko (2014).

LnRealmaizeprice, a short-run variable, indicates that real price of maize as a competing crop was statistically significant at $10 \%$ with a coefficient of -0.49 carrying an expected negative sign. This means that the price of the competing crop negatively influences the area of sorghum planted. Hence, when the price of maize increases by one rand (ZAR 1.00), the planned area of sorghum will decrease by 0.49 hectares since farmers reallocate their resources towards more rewarding crops (maize). The long-run price elasticity of maize was statistically significant at $1 \%$ with a coefficient of -1.15 . The long-run magnitude is greater than the shortrun, implying that area allocation is more responsive to price changes in the long than in the short-run. These results are in line with Anwarul Huq and Arshad (2010) and Munyati et al. (2013) wherein it was found that the sorghum sector is highly sensitive to changes in maize prices.

LnSorghumton, the short-run sorghum output, was statistically significant at $10 \%$ with a coefficient of 0.77 . This is less than unity and reflects the inelastic supply of the crop. The positive sign of yield was expected because when tons of sorghum per hectare are increasing, the producers tend to increase the area under sorghum production. The long-run sorghum output was statistically significant at $1 \%$. The long-run elasticity showed an increase with a coefficient of 0.85 tons per hectare; this indicates a greater improvement in tons-per-hectare in the long than in the short-run. Hence, better yields will infer more profits and the reallocation of more land towards sorghum production.

LnTech, the short-run technological change, was statistically significant at $10 \%$ and positively influenced the area under sorghum production with a high coefficient of 8.4. As a consequence of technological improvements, 8.4 hectares will planted in the subsequent period. This implies that improvements in the knowledge of farmers, level of fertilization, use of herbicides, seeds variety, mechanization, extension services, change of policies etc. all have a great influence on the area of sorghum planted. The long-run technological improvement was statistically significant at $1 \%$ with a magnitude of 3.78 , and was elastic. Mutua (2015) found a very low magnitude 
of the coefficient (0.008) of technological change and concluded that the study period witnessed only a minimal technological change in the sugarcane sub-sector.

LnRainfall, the short-run average annual rainfall received, was statistically significant at $10 \%$ with a coefficient of 0.89 , and positively influenced the area under sorghum production. However, the coefficient was inelastic, suggesting that an increase in rainfall by one percent would result in a 0.89 percent increase in the area of sorghum planted. The positive sign was expected as rainfall tends to have a positive relationship with crop production. In the long-run, rainfall was significant at $1 \%$ and was elastic with a coefficient of 1.69 , implying that area allocation is more responsive when the country receives enough rainfall.

The error correction term, which measures the speed of adjustment to long-run equilibrium, was statistically significant with an expected negative sign. This indicates that the model was able to revert to equilibrium after an economic shock. The coefficient of error correction term was -1.55 , implying that area allocation was able to recover from short-run disequilibrium and revert to its long-run mean within one period (one year).

Table 8. Model 2, VECM results: yield/output response function

\begin{tabular}{lcccc}
\hline \multicolumn{1}{c}{ Variables } & $\begin{array}{c}\text { Short-run } \\
\text { elasticities }\end{array}$ & $\begin{array}{c}\text { Test } \\
\text { sta- } \\
\text { tistics } \\
(z)\end{array}$ & $\begin{array}{c}\text { Long-run } \\
\text { elasticities }\end{array}$ & $\begin{array}{c}\text { Test } \\
\text { sta- } \\
\text { tistics } \\
(z)\end{array}$ \\
\hline LnSorghumton $_{\mathrm{t}-1}$ & 0.10 & 0.14 & 1 & - \\
LnSorghumha $_{\mathrm{t}-1}$ & 0.14 & 0.14 & $-1.17^{*}$ & -18.34 \\
LnTech $_{\mathrm{t}-1}$ & $4.8^{* * *}$ & 1.85 & 0.31 & 0.01 \\
LnRealsorprice $_{\mathrm{t}-1}$ & 0.66 & 0.69 & $-2.06^{*}$ & -9.49 \\
LnRealmaizeprice $_{\mathrm{t}-1}$ & 0.66 & 0.41 & -0.16 & -1.03 \\
LnRainfall $_{\mathrm{t}-1}$ & 0.26 & 0.41 & $0.80^{*}$ & 7.07 \\
Constant & -18.22 & -0.35 & 148.95 & - \\
Error correction term & -1.30 & -1.38 & -1.30 & -1.38 \\
Adj. $\mathrm{R}^{2}(0.70)$ & & & & \\
Log likelihood $(0.32)$ & & & & \\
P>chi & & & & \\
\hline
\end{tabular}

$* * *$ Significant at $10 \%$.* Significant at $5 \%$. Significant at $1 \%$ Source: own elaboration.
The coefficient of determination (adjusted $\mathrm{R}^{2}$ ) presents the supply model's goodness of fit. The magnitude of 0.76 means that the regressor variables explain about $76 \%$ of the variation in the area response function. A log-likelihood ratio (0.97) closer to one implies a better fit, showing that the model fits the data well (Gujarati and Porter, 2009).

\section{Model two: output response function}

LnRealsorprice, the short-run single-lagged real price of sorghum, was statistically insignificant. The long-run own price was statistically significant at $1 \%$ with a coefficient greater than unity $(-2.06)$, implying that a onerand increase in own price will decrease sorghum output by 2.06 tons. This was not expected, since the economic theory states that a positive relationship exists between the price of the commodity and the product in question. This means that sorghum output is not responsive to price incentives.

LnRealmaizeprice, the real price of maize as a competing crop, was statistically insignificant in both the short and long-run.

LnSorghumha, the short-run lagged area of sorghum planted, was not statistically significant. The long-run area of sorghum planted was significant at $1 \%$ with a coefficient of -1.17 , implying that any adjustment of the area will result in a reduction of sorghum output by 1.17 tons.

LnTech, the short-run technological change, was statistically significant at $10 \%$, had a positive influence on sorghum output with a very high coefficient of 4.8 , and was elastic. The long-run coefficient $(0.31)$ was inelastic. Surprisingly, the short-run technological improvement is more responsive than in the long-run. This was not expected as output tends to improve with time and experience gained by farmers in the long run rather than in the short run.

LnRainfall, the short-run average annual rainfall received, was statistically insignificant. In the long-run, it became significant at $1 \%$ but inelastic $(0.80)$. The error correction term was statistically insignificant $(-1.30)$. The coefficient of determination (adjusted $\mathrm{R}^{2}$ ) presents the supply model's goodness of fit. The magnitude of 0.70 means that the regressor variables explain about $70 \%$ of the variation in the yield response function. A log-likelihood ratio of 0.32 was obtained (Gujarati and Porter, 2009). 


\section{Comparison of the two models}

The two models were assessed based on the significance of the coefficient, $\log$ likelihood, $P>\mathrm{Chi}^{2}$ and the goodness of fit of the models. It was ascertained that the area is more preferred than the output response function, since sorghum production proved to be more responsive to the area than to the yield function. Thus, the area response function was found to be a robust model. This could be due to the fact that acreage is believed to be more subject to farmer's control than output, and implies that farmers have control over the area allocation decisions. Rao (1988) ascertained that yield elasticity is smaller and less stable than acreage elasticity. These findings on short-run and long-run elasticity are consistent with those of other authors, namely Alhaji et al. (2014) and Shoko (2014).

\section{CONCLUSION AND RECOMMENDATIONS}

Area allocation was highly responsive to technological change and own price. However, price elasticity of maize had a negative influence on sorghum area allocation in South Africa. Therefore, it was concluded that sorghum producers were slightly flexible in their area allocation decisions in the short run. Nevertheless, in the long run, they were more flexible when it comes to allocating more land to sorghum production. In the yield response function, only few variables were statistically significant. Thus, it was concluded that this model was not robust and hence was not adopted. Furthermore, model one was found to be robust, as sorghum production proved to be more responsive to the area than yield function. Based on the findings, the study recommends that amongst other methods to enhance sorghum output, producers could use improved varieties or hybrids, as this action would result in allocation of more land to sorghum production, following price change.

\section{REFERENCES}

Alemu, Z. G., Oosthuizen, K., van Schalkwyk, H. D. (2003). Grain-supply response in Ethiopia: An error-correction approach. Agrekon., 42(4), 389-404.

Alhaji, M., Conteh, H., Yan, X., Gborie, A. V. (2014). Using the Nerlovian adjustment model to assess the response of farmers to price and other related factors: Evidence from Sierra Leone rice cultivation. Int. J. Soc. Behav. Edu. Econ. Bus. Indust. Eng., 8(3), 1-7.
Anwarul Huq, A. S. M., Arshad, F. M. (2010). Supply response of potato in Bangladesh: A vector error correction approach. J. Appl. Sci., 10(11), 895-902.

Belete, A. (1995). Economic analysis of supply response among summer wheat growers in Lesotho. UNISWA J. Agric., 4, 55-80.

Belete, A., Fraser, C. G., Trollip, I. R. F. (1995). Econometric estimation of a supply function: An empirical example from agriculture. A guide to supply response analysis, working paper No. 1, 6-27.

DAFF (Department of Agriculture, Forestry and Fisheries) (2010). Sorghum production guideline. Annual report 2009-2010 (pp. 13-28). Retrieved Feb 13 ${ }^{\text {th }}$ 2017: www. nda.agric.za/SorghumProductionguideline2010

DAFF (Department of Agriculture, Forestry and Fisheries) (2015). A profile of the South African grain sorghum market value chain. Annual report 2014-2015 (pp. 6-27). Retrieved April 13 2017 from: www.nda.agric.za/ GrainSorghumMarketValueChainProfile2015

Gujarati, D. N., Porter, D. C. (2009). Basic Econometrics. Fifth edition. The McGraw-Hill Series Economics, 557758. New York, USA.

Hallam, D., Zanoli, R. (1993). Error correction models and agricultural supply response. Eur. Rev. Agric. Econ., 20, 151-166.

Johansen, S. (1988). Statistical analysis of cointegration vectors. J. Econ. Dyn. Control, 12, 231-254.

McKay, A., Morrissey, O., Vaillant, C. (1998). Aggregate export and food crop supply response in Tanzania. Centre for research in economic development and international trade, University of Nottingham. Credit research paper No. 98(4), 4-34.

Mose, L. O., Burger, K., Kuvyenhoven, A. (2017). Aggregate supply response to price incentives: The case of smallholder maize production in Kenya. African crop science conference proceedings, 8 (pp. 1271-1275).

Munyati, V., Mugabe, D., Chipunza, N., Mafuse, N., Chagwiza, G., Musara, J. (2013). An econometric approach to ascertain sorghum supply response in Zimbabwe. Afr. J. Agr. Res., 8(47), 6034-6038.

Mutua, M. M. (2015). An estimation of sugarcane supply response among out-growers in Mumias sugar company. Masters' thesis. University of Nairobi, Kenya (pp. 38-60).

National Agricultural Marketing Council (2007). Report on the investigation into the South African sorghum industry: Annual report 2006-2007 (pp. 25-47).

Nerlove, M. 1958. The dynamics of supply: Estimation of farmers' response to Price. Am. J. Agric. Econ., 41(2), 452-455.

Nmadu, J. N. (2010). Revision of the Nerlovian partial adjustment framework and its application to sorghum production 
in Nigeria. Afr. J. Agric. Res., 5(5), 25-31. Retrieved Feb $15^{\text {th }} 2017$ from: http://www.academicjournals.org/AJAR

Paltasingh, K. R., Goyari, P. (2013). Supply response in rainfed agriculture of Odisha, Eastern India: A vector error correction approach. Agric. Econ. Rev., 14(2), 89-104.

Shoko, R. R. (2014). Estimating the supply response of maize in South Africa. Masters' thesis, University of Limpopo, South Africa (pp. 51-66).

Sihlobo, W., Kabuya, T. (2015). Grain market overview. Grain SA. Retrieved April 12 2017 from: http://www.grainsa. co.za/grain-market-overview-3
StataCorp. (2011). Stata time series reference manual release 12. Stata Press, 418-754.

Townsend, R., Thirtle, C. (1997). Dynamic acreage response: An error correction model for Maize and Tobacco in Zimbabwe. Occasional Paper Series No. 7 198059, International Association of Agricultural Economists. Retrieved from: https://ideas.repec.org/p/ags/iaaeo7/198059.html 